\section{World Congress on Osteoarthritis 2015}

Hvorfor tror du du har artrose? Hva kan vi gjøre for at færre får det, eller for at konsekvensene av det blir færre? For å belyse slike, og mange flere spørsmål, var ca. 2000 artroseforskere fra hele verden samlet i Seattle 30.4. - 3.5.2015. Fra Revmatologisk avdeling på Diakonhjemmet sykehus var vi tre utsendte, og vi har sammenfattet hvor artroseforskningen står ut fra vår forskningsinteresse som er håndartrose og risikofaktorer for artrose.

For å kunne studere artrose og forebygge forverring, er det svært viktig å oppdage tilstanden tidlig. Det er tydelig at ultralyd er en modalitet med økende interesse, men som det enda ikke er gjort mye forskning på. Faktisk er Norge og Diakonhjemmet Sykehus blant de fremste i verden på nettopp dette, og vi får stadig ny kunnskap om ultralyd som et diagnostisk supplement til tradisjonell røntgen. Vi vet nå at ultralyd kan oppdage artrose på et tidligere tidspunkt enn røntgen, både fordi ultralyd kan visualisere leddbrusken direkte, og fordi ultralyd kan oppdage benete påleiringer ("osteofytter") lettere enn røntgen. Dessuten har man med ultralyd vist at inflammasjon ved artrose er hyppigere enn vi trodde, og at disse leddene oftere forverres enn ledd uten inflammas-

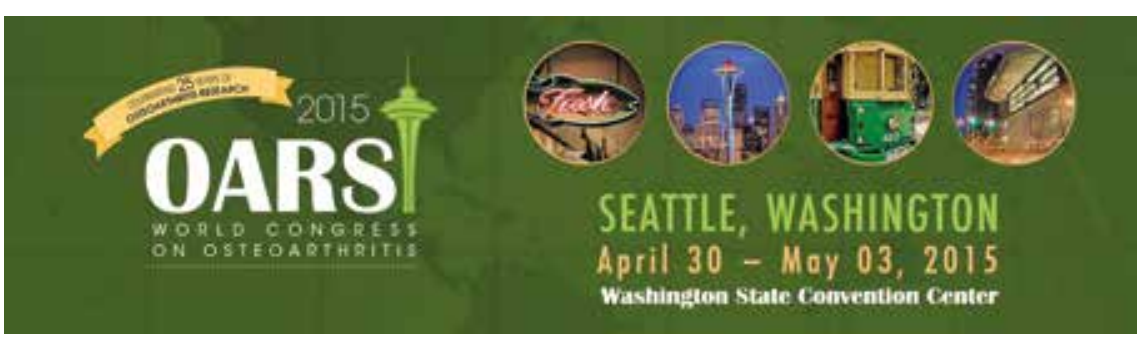

jon. I fremtiden kan dette vise seg å være et mål for behandling.

I år var det større fokus på inaktivitet og stillesitting som risikofaktor, fremfor mangel på strukturert trening og fysisk aktivitet som var hovedfokus tidligere. Kongressen ga ytterligere bevis for at artrosepasienter bør drive fysisk aktivitet og minske stillesitting. Hele kongressens abstrakter kan leses på http://www.oarsijournal.com/issue/S1063-4584(15)

X0005-7.

Sammenfattende var dette en lærerik kongress der vi ikke bare fikk høre siste nytt innen artroseforskning, vi ble også kjent med andre forskere med samme interesser, fikk nye ideer, motivasjon og inspirasjon til nye forskningsprosjekter.

Karin Magnusson, Alexander Mathiessen, Ida Kristin Bos-Haugen

Alexander Mathiessen fikk prisen for beste frie foredrag ved årets NFUD symposium og er nominert fra NFUD som Young Investigator for EFSUMB/EUROSON 6.-8. november 2015 i Athen. 